\title{
GaAs Solar Cells Application in Spacecraft Power System
}

\author{
Fei WANG* \\ Beijing Institute of Spacecraft System Engineering \\ Beijing, 100094, China \\ e-mail: wangfeiaa110@163.com \\ Xiao-feng ZHANG \\ Beijing Institute of Spacecraft System Engineering \\ Beijing, 100094, China \\ Wei-feng GUO \\ Beijing Institute of Spacecraft System Engineering \\ Beijing, 100094, China \\ Wen-jia ZHANG \\ Beijing Institute of Spacecraft System Engineering \\ Beijing, 100094, China
}

\begin{abstract}
As a kind of power generation setup in the spacecraft, GaAs solar cells convert the solar energy into the electric power and satisfy the demand of power loads in the spacecraft. Ground irradiation experiment and in-orbit output power date were given in the article, which showed that the energetic particles could cause defects in the semiconductors and lower the electric performance. So special cell-structure design should be carried out for special space orbits in the satellite design. GaAs solar cells with higher efficiency, lower weight, and perfect anti-irradiation characteristics are desired to meet the demand of future space application.
\end{abstract}

\section{Keywords- GaAs; Solar Cells; Spacecraft}

\section{INTRODUCTION}

\section{A. Spacecraft Power System}

Power system is a subsystem of the spacecraft. The main function of the spacecraft power system is to generate, regulate, transmit, distribute and storage the electric power in the whole lifecycle of the spacecraft, including the launching period and the in-orbit working period.

Spacecraft power system is mainly composed of three parts, including the generation, regulation and storage units. Currently, the main power generation unitis contributed by solar cells, fuel cells, or nuclear power; the power storage unit is mainly composed with batteries, for example, $\mathrm{Cd}-\mathrm{Ni}$

\author{
Zhi-gang LIU \\ Beijing Institute of Spacecraft System Engineering \\ Beijing, 100094, China
}

\author{
Hai-tao SUN \\ Beijing Institute of Spacecraft System Engineering \\ Beijing, 100094, China \\ Wen-li LIN \\ Beijing Institute of Spacecraft System Engineering \\ Beijing, 100094, China \\ Qi CHEN \\ Beijing Institute of Spacecraft System Engineering \\ Beijing, 100094, China
}

batteries, Ni-H batteries, or Li-ion batteries; power controlling unit is to regulate the direct current (DC) from the generation setup into DC which can be used by the electric load, and a few methods can be used for power controlling, such as S3R(Sequential Switching Shunt Regulator), S4R (Serial Sequential Switching Shunt Regulator) and MPPT (Maximum Power Point Tracking) regulations.

\section{B. GaAs Solar Cells R\%D and Applications}

At the beginning period of space exploration, silicon solar cells were mainly used to generate electric power for the spacecraft, and power conversion efficiency of Si cells was about $10 \% \sim 15 \%$. With the development of space exploration enterprise, demands for high efficiency and lightweight solar cells was more vehement. Until 1990, GaAs solar cells was still at the R\&D(research and development)level, and a few problems had to be solved, such as lattice mismatch, defects at the interface, and serious recombination of charge carriers. After the industrialization of MOCVD method, technology of crystal growth was sharply improved, and the efficiency of GaAs solar cells enhanced quickly. Since the MOCVD technology started from Western countries, they still hold the efficiency records of GaAs solar cells after many years' development, both in the fields of technology and products. 


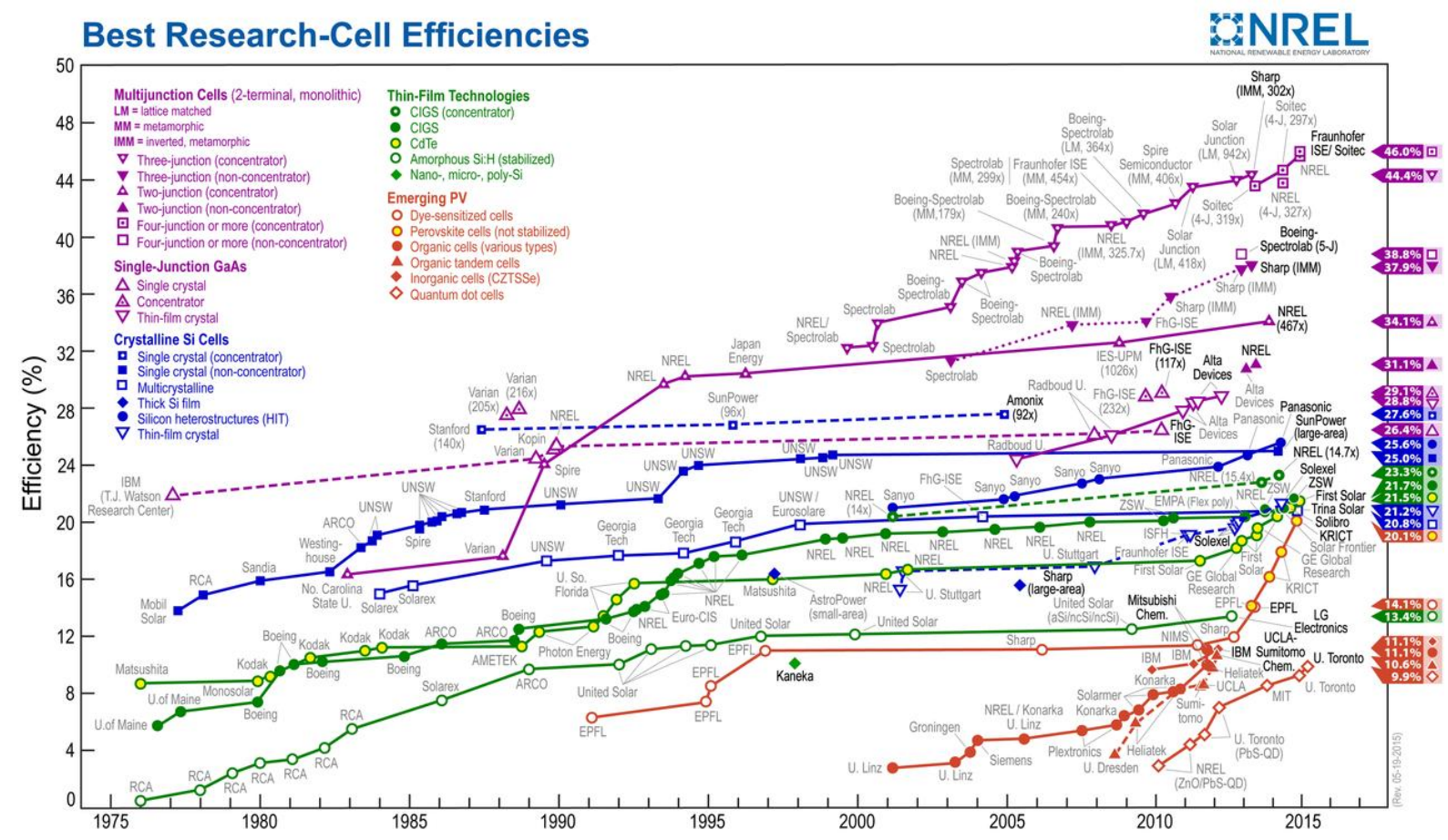

Figure 1. Road map of solar cells on the Earth. (given by NREL in 2015)

NREL (National Renewable Energy Laboratory) showed the road map of worldwide photovoltaic development in 2015, see Figure 1. The efficiency and research institutions were both given on the map.

Seen from the road map and indexed from research papers, efficiency information of GaAs solar cells was concluded in Table 1.

TABLE I. EFFICIENCY TABLE OF GAAS SOLAR CELLS (AM1.5 SPECTRUM) $[1,2,3]$

\begin{tabular}{|c|c|c|c|}
\hline \multirow{2}{*}{$\begin{array}{l}\text { Products } \\
\text { Single-Junction, Concentrate }\end{array}$} & \multicolumn{2}{|c|}{ Efficiencr Institution } & \multirow{2}{*}{$\frac{\text { Notes }}{117 \text { suns }}$} \\
\hline & $d 29.1 \%$ & FHG ISE & \\
\hline Single-Junction, Un- & $28.8 \%$ & ALTA & \\
\hline concentrated & & DEVICES & \\
\hline Two-Junction, Concentrated & $34.1 \%$ & NREL & \\
\hline $\begin{array}{l}\text { Two-Junction, Un- } \\
\text { concentrated }\end{array}$ & $31.1 \%$ & NREL & \\
\hline Three-Junction, Concentrated & $144.4 \%$ & SHARP & 302 suns, $\mathrm{IMM}^{\mathrm{a}}$ \\
\hline $\begin{array}{l}\text { Three-Junction, Un- } \\
\text { concentrated }\end{array}$ & $37.9 \%$ & SHARP & IMM \\
\hline Four-Junction, Concentrated & $46 \%$ & FHG, ISE & 508 suns, \\
\hline $\begin{array}{l}\text { Four-Junction, Un- } \\
\text { concentrated }\end{array}$ & I & & \\
\hline Five-Junction, Concentrated & I & & \\
\hline $\begin{array}{l}\text { Five-Junction, Un- } \\
\text { concentrated }\end{array}$ & $38.8 \%$ & SPECTROLAF & \\
\hline
\end{tabular}

Note: Table notes
aIMM: Inverted Metamorphic Growth

GaAs based solar cells has been developed from singlejunction cells on GaAs substrate, two-junction cells on GaAs substrate, two-junction cells on Ge substrate, and threejunction (TJ) cells on Ge substrate. In current, the most common product for spacecraft is the three-junction devices. The lab-efficiency record for three-junction GaAs device is as high as $37.9 \%$, tested under AM1.5, $25^{\circ}$ Cconditions, and fabricated by Sharp Corp. The efficiency of on-line GaAs products for spacecraft is about 30\%, both in China and abroad. The structure and optical response is shown in Figure 2.

The three-junction GaAs device is composite of Ge bottom cell with $0.66 \mathrm{eV}$ bandgap, GaInAs middle cell with $1.41 \mathrm{eV}$ bandgap, and GaInP top cell with $1.87 \mathrm{eV}$ bandgap to harvest sunshine in different solar spectrum zone.

Spectrum response of TJ GaAs solar cells is from $300 \mathrm{~nm}$ to $1800 \mathrm{~nm}$, which is wider than any other kind of solar cells, such as $\mathrm{Si}, \mathrm{CuInGaSe} 2$, and $\mathrm{GeTe}$ based devices. Although, there is still space to improve the performance. In TJ cell, much more photo current is induced than that of the other two junctions, that is to say, numerous charge carriers recombine in Ge body before reaching to the tunnel diode or the electrode. The best way to reduce the current in the Ge subcell is to increase the red-zone spectrum response of middle and top cells effectively, and generates more current. To realize this goal, two methods could be applied, the first one is depress the energy band of middle and top cells, for example, to fabricate a $0.66 \mathrm{ev} / 1.4 \mathrm{ev} / 1.8 \mathrm{ev}$ TJ structure; another way is to build the fourth or more junction to harvest part of the red-zone spectrum, such as the $\mathrm{Ge}(0.66 \mathrm{ev}) / \mathrm{GaInNAs}(1.0 \mathrm{ev}) / \mathrm{GaInAs}(1.4 \mathrm{ev}) / \mathrm{GaInP}(1.9 \mathrm{ev})$ structure. 
(a)
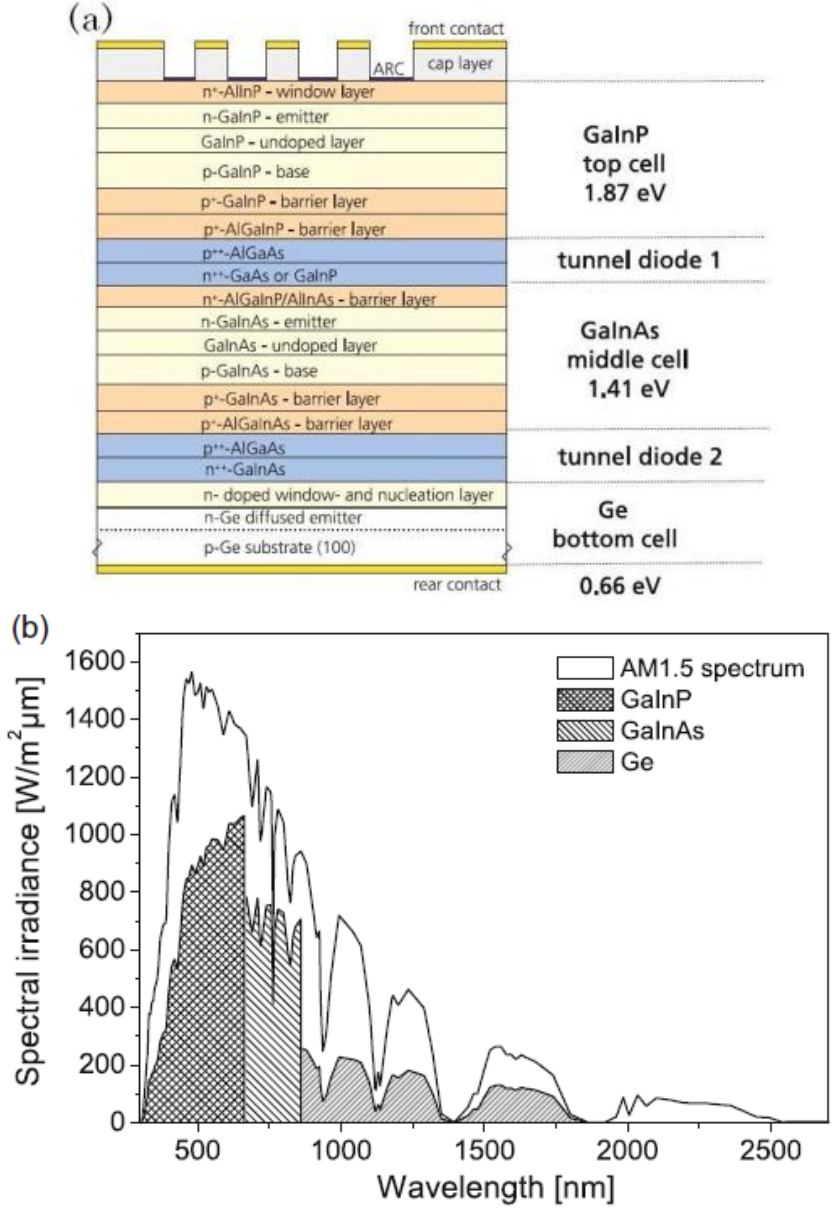

Figure 2. Structure of three-junction GaAs solar cells (a), and spectral response (b).

\section{IRRADIATION CHARACTERISTICS}

\section{A. $1 \mathrm{MeV}$ Electrons Equivalent Irradiation Experiment}

In space, the environment is rather complicated, with kinds of energetic electrons and ions. When energetic particles attack GaAs solar cells on the solar panels of spacecraft, it will damage GaAs crystal lattice and causes defects in the body. So, to protect the GaAs solar cells from being attacked fierily, a Ce mixed cover glass is commonly pasted on the devices with silicone glue, and some particles with low energy could be arrested and particles with high energy could be lowered down.

Theoretically, an assessment methodology for the singlejunction GaAs solar cells has been established for many years on the basis of studying the radiation damage effects induced by energetic particles. [4] Recently, the evaluation of the multi-junction GaAs cells has drawn more attention. The radiation effects on $\mathrm{InP} / \mathrm{Si}$ and $\mathrm{GaInP} / \mathrm{GaAs}$ doublejunction cells were investigated and their performance in orbit was evaluated by a displacement damage model [5]. T. Sumita et al. studied and concluded that the lower-energy protons with a few hundreds of $\mathrm{keV}$ could cause a more severe damage in the $\mathrm{GaInP} / \mathrm{GaAs} / \mathrm{Ge}$ triple-junction solar cells [6].

To evaluate the damage of the energetic particles on GaAs cells, an equivalent irradiation experiment is commonly used. Damage by different energetic particles are converted into damage by $1 \mathrm{MeV}$ electrons with an equivalent coefficient.

An experiment on the irradiation damage on TJ GaAs solar cells was done, and the result was shown in Figure 3.

Seen from the figure, when the flux of $1 \mathrm{MeV}$ electrons increases, the performance characteristics of GaAs decays, and the decay rates increases simultaneously. For a satellite in GEO(35786 km height) or LEO (200 800 km height) orbits, the equivalent irradiation flux of $1 \mathrm{MeV}$ is below $1 \times 10^{15} / \mathrm{cm}^{2}$. So the solar cells in orbit could be derived from this curve, which is also the method being used in the power system designing process for satellites currently.

\section{B. Data in Orbit}

$\mathrm{XX}$ satellite is a GEO satellite, which was launched in August 2011.On the satellite, a Solar Array Drive Assembly (SADA) is applied to maintain the solar panels perpendicular to the sunshine, so as to make the best of solar energy. While, to execute some special tasks sometimes, the satellite pose should be changed and the solar panels turn a certain angle simultaneously. When analyzing the output electric energy from the solar panels, this angle information should be considered and excluded. Temperature information should also be concerned, so the data here are normalized to $25^{\circ} \mathrm{C}$.
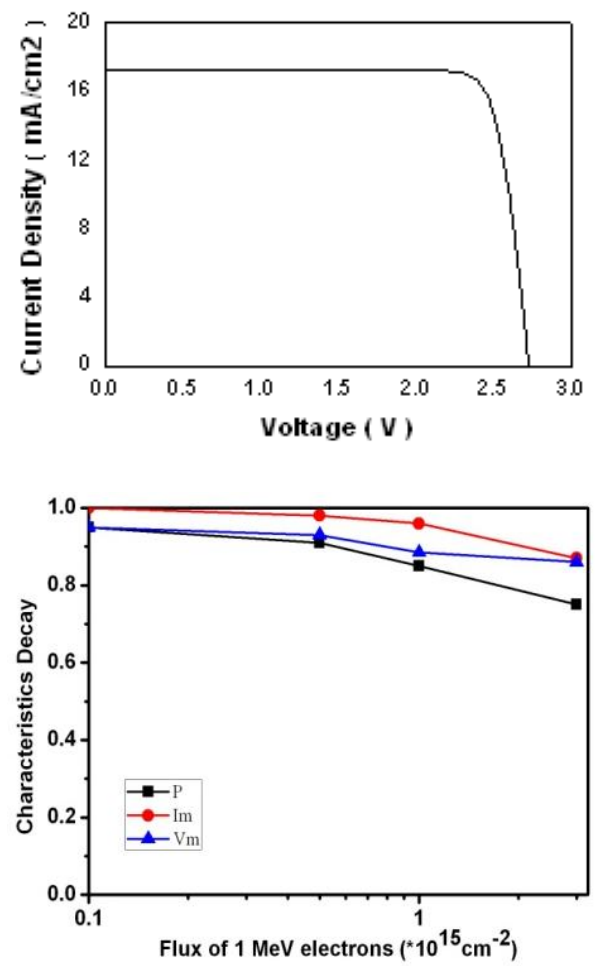

Figure 3. Characteristics decay of TJ GaAs solar cells with different flux of $1 \mathrm{MeV}$ electrons irradiation.(left: I-V characteristic; right: characteristics decay) 

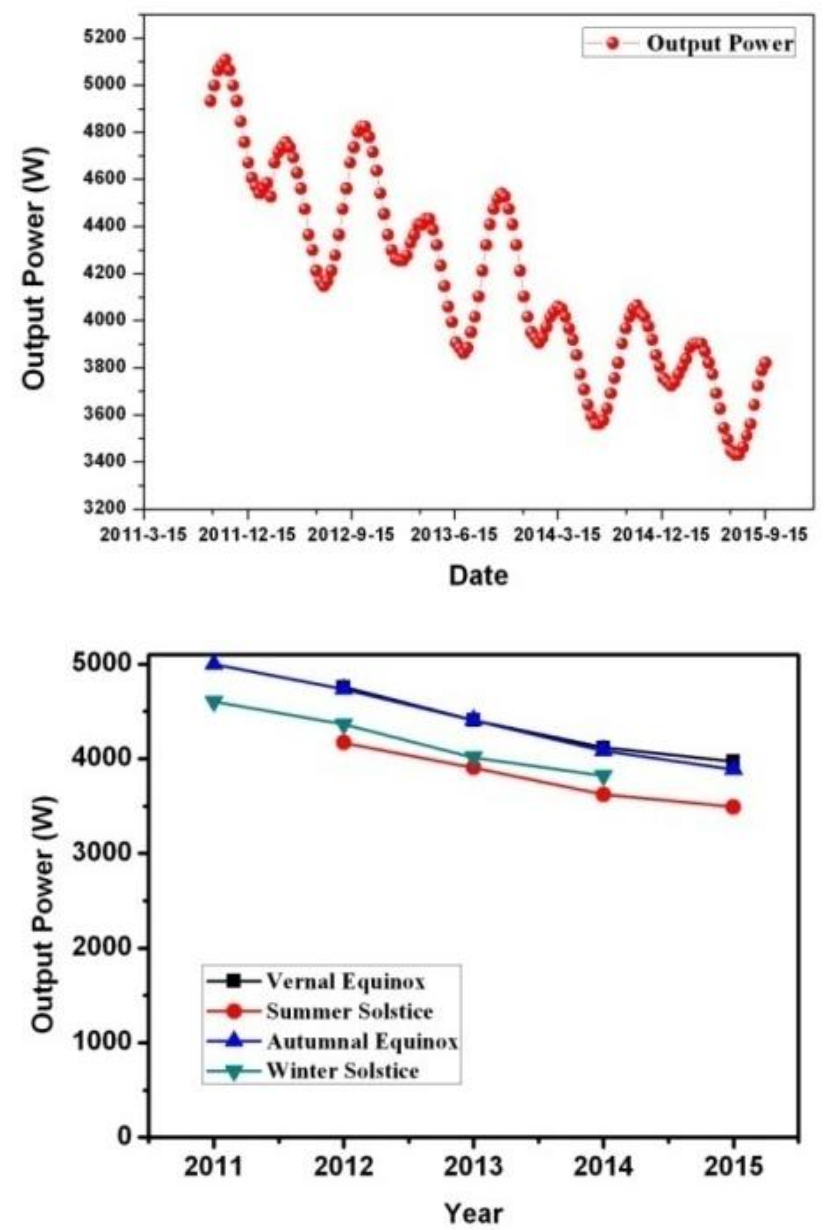

Figure 4. Characteristics decay of TJ GaAs solar cells with different flux of $1 \mathrm{MeV}$ electrons irradiation (left), and output power of the solar panel on Solstice and Equinox (right).

Seen from Figure 4, the output power declines when the satellites' serving time goes longer. Another phenomenon is that the fluctuation of the curve in a year, and the reason for that is the solar irradiance changes with the distance from the sun to the earth, and that means season changes on the Earth, and the intensity coefficient turns from 0.9673 in Summer to 1.0327 in Winter. So it is necessary to analyze the output power on the same date of a year, and the power data on Equinox and Solstice is shown in the right picture.

From the output power curve, we can see that the power of the solar panels slightly declines with serving time, which is due to many reasons. First of all, the energetic particles damage on the GaAs solar cells, which may be the most important reason, and also the most different condition from solar cells used on the Earth; Secondly, since the solar cells are protected with a kind of glass from the space particles, and the cover glass was adhibited with silicone rubber, which is a kind of polymer, the ultraviolet light of the sunshine will damage the molecule structure, and the transmittance would lower down.

Lots of work is to be done to protect the solar cells from being damaged by the space serious conditions. Since the energy and flux of energetic particles in LEO, GEO or other orbits differ from each other, designing special antiirradiation GaAs solar cells for the satellite to adapt the orbit conditions is the best way. Another way is to develop a new kind of anti-UV glue to adhibit the cover glass and the cells.

\section{CONCLUSIONS}

Power subsystem supply the electric power for the spacecraft, which mainly possesses three parts, and the power-generation setup is the most important one. High efficiency GaAs has been developed and applied in the spacecraft, with the demand for more electric power. Ground experimental and in-orbit date show that the energetic particles could cause defects in the semiconductors and lower the electric performance. Special cell-structure design should be carried out for special space orbits, and anti-UV glue could also be used to adhibit the cover glass and the cells for the solar panel application.

In the future, with the development of the space tasks and the desire of high power laser beam weapons, higherefficiency, lower-weight and anti-irradiation GaAs will be researched and finally used in the spacecraft, after passing a list of tests, including mechanism characteristic tests, thermodynamic tests, energetic particle irradiation tests and so on.

\section{ACKNOWLEDGMENT}

Work partially supported by grant $6140655010216 \mathrm{HT}$ 51001 and 41423060209 of the Central Military Commission Fund.

\section{REFERENCES}

[1] B.M. Kayes, et al., 27.6\% conversion efficiency, a new record for single-junction solar cells under 1 sun illumination. Proceedings of the 37th IEEE PVSC, 2011, 4.

[2] http://www.ise.fraunhofer.de/en/press-and-media/pressreleases/pressreleases-2014/new-world-record-for-solar-cellefficiencyat-46-percent on 7 December 2014.

[3] P.T. Chiu, et al., $35.8 \%$ space and $38.8 \%$ terrestrial $5 \mathrm{~J}$ direct bonded cells, Proceedings of the 40th IEEE PVSC, 0011, (2014).

[4] R. Wang, Z. Guo, G. Wang, Low-energy proton irradiation effects on GaAs/Ge solar cells, Sol. Energy Mater. Sol. Cells 90,1052 (2006).

[5] R.J. Walters, H.L. Cotal, S.R. Messenger, E.A. Burke, et al., Radiation response of InP/Si and InGaP/GaAs space solar cells, Sol. Energy Mater. Sol. Cells 50, 305 (1998).

[6] T. Sumita, M. Imaizumi, S. Matsuda, T. Ohshima, A. Ohi, H. Itoh, Proton radiation analysis of multi-junction space solar cells, Nucl. Instrum. Methods B 206, 448 (2003). 